Sri Lanka J. Aquat. Sci. 11 (2006): 85-91

\title{
Influence of different processing methods on quality and shelf life of dried shrimp
}

\author{
P.S. JAY ASINGHE* ， J.M.P.K. JAY ASINGHE AND C.P. \\ GALAPP A THTHI
}

${ }^{1}$ Post Harvest Technology Division, National Aquatic Resources Research and Development Agency, Crow Island, Mattakkuliya, Colombo 15, Sri Lanka.

${ }^{2}$ Department of Fisheries and Aquaculture, Faculty of Livestock, Fisheries and Nutrition, Wayamba University of Sri Lanka, Makandura (NWP), Sri Lanka

*Corresponding author: pradeepa_j@ hotmail.com

\begin{abstract}
Marine shrimp fishery contributes around 55\% to the small shrimp production Sri Lanka. In addition to the targeted large shrimp for the export market, small shrimp are marketed locally as value added dried products. This activity has been established as a cottage industry. Development of optimum control conditions of processing is very important for maintaining nutritional quality of the dried shrimp. Present study was conducted to evaluate the effect of different salt concentrations, cooking methods, drying time and drying temperature on sensory properties of processed whole and peeled shrimp with a view to develop improved processing methods. In addition, sensory properties, total volatile nitrogen (TVN) content, trimethylamine (TMA) content and total bacterial count (TBC) of the processed whole and peeled shrimp which had been stored under different packaging systems viz. polythene bags, Styrofoam boxes and open bulk packages were assessed weekly for six weeks to determine the shelf life of the processed shrimp.

The results revealed that the whole shrimp salted at 5\%(w/w), pressure cooked for 20 minutes, dried at $70^{\circ} \mathrm{C}$ for 2 hours and the peeled shrimp treated under the same conditions and cooked only for 10 minutes gave the best quality dried shrimp. TVN contents (in $\mathrm{mg} / 100 \mathrm{~g}$ ) in whole dried shrimp packed in Styrofoam box, polythene bags and under bulk packages were $25,34.5$ and 39.5 respectively at the end of six weeks. TMA contents (in $\mathrm{mg} / 100 \mathrm{~g}$ ) in whole dried shrimp stored in three types of packing systems mentioned above were $16.8,21$, and 26.3 respectively whereas
\end{abstract}


TBC values (in $\mathrm{cfu} / \mathrm{g}$ ) for dried whole shrimp were $1.08 \times 16,1.08 \times 10^{6}$ and $1.66 \times 10^{6}$. TVN contents (in $\mathrm{mg} / 100 \mathrm{mg}$ ) in the peeled dried shrimp packed in Styrofoam box, polythene bags and under bulk packages were 27, 16.8, and 21 respectively whereas the TMN contents (in $\mathrm{mg} / 100 \mathrm{~g}$ ) were $16.8,15$ and 25.2 at the end of the six weeks. TBC values (in cfu /g) of these processed peeled shrimp packed in Styrofoam, polythene and bulk packages were $5.88 \times 10^{4}, 1.66 \times 10^{5}$ and $3.33 \times 10^{5}$ respectively. Styrofoam package was found to be the most effective packaging system for both processed whole and peeled dried shrimp.

\section{Introduction}

In the past, shrimp industry of Sri Lanka depended mainly on the wild shrimp catch. At present cultured shrimp also make a substantial contribution to the shrimp production and more than $60 \%$ of shrimp production is exported (Jayasinghe 1995). However, substantial portion of the low value small shrimp varieties such as Metapenaeus dobsoni, Penaeus indicus and Parapenaeopsis coromandelica are used for local consumption as they are not accepted for export market. Small shrimp are mainly used for preparation of salted, value added and dried products. In processing shrimp, adoption of proper handling practices in the production process is important to obtain a high quality nutritional product with higher consumer demand. It would also prolong the shelf life of the value added product.

Present study was conducted to evaluate the effects of different salt concentrations, cooking methods, drying times and drying temperatures on sensory properties of processed whole and peeled shrimp with a view to develop improved processing methods. It was attempted to determine the optimum processing conditions to maintain the natural quality of the whole and peeled processed shrimp. In addition, organoleptic properties, total volatile nitrogen (TVN) content, trimethylamine (TMA) content and total bacterial count (TBC) of the processed whole and peeled shrimp which had been stored under different packaging systems viz. polythene bags, Styrofoam box and open bulk packages were assessed weekly for six weeks to determine the shelf life of the processed shrimp.

\section{Materials and Methods}

Several Penaeus indicus samples (3 $\mathrm{kg}$ each) were collected from lagoon and coastal trawl fishery in Negombo and transported to the processing plant at National Aquatic Resource Research and Development Agency (NARA) at $0{ }^{\circ} \mathrm{C}$ in ice packs and subsequently stored in a deep freezer at $-20{ }^{0} \mathrm{C}$ for 24 hours. Shrimp samples were thawed in a flooded water container for one hour. Then samples were washed with chlorinated 
chilled water until washing water became clear. The samples of shrimp were divided into two parts $(1 \mathrm{~kg}$ each) and one portion was processed without peeling and other was peeled. The samples from each whole (unpeeled) and peeled shrimp were divided into several sub-portions and subjected to different treatments in triplicates as described below.

\section{Treatment 1 - Determination of optimum salt concentration}

Initially an attempt was made for evaluation of most palatable salt content from the four different salt percentages for both types of shrimp. Four different salt percentages $(3 \%, 5 \%, 7 \%$ and $10 \%, w / w)$ were added and allowed to season for 30 minutes. Both types of shrimp were washed just after 30 minutes of salting and sensory evaluation was carried out for colour, odour, flavor and texture based on a 5 point hedonic grading scale $(5=$ Excellent, $4=$ good, $3=$ Fair , $2=$ poor, $1=$ unacceptable). The best acceptable salt concentration was detected by trained panelists: a panel of seven judges. A score card was prepared to evaluate the quality of shrimp as described by Soudan (1978). Selected salted shrimp samples were stored in the deep freezer after sealing in the polythene bags for the rest of the experiments.

\section{TreatmentП - Determination of optimum cooking time}

Whole and peeled shrimp samples treated with best acceptable salt content $(5 \% \mathrm{w} / \mathrm{w})$ from the treatmentI, was used for the treatment $\Pi$. Sub samples of $250 \mathrm{~g}$ each from the salted whole and peeled samples were used for the cooking process. Four different time durations $(10,15,20$ and 25 minutes) were tested using a pressure cooker. Optimum cooking time was evaluated using the same sensory evaluation procedures as described above.

\section{Treatment 111 - Determination of optimum drying time and drying temperatures}

The shrimp samples having the best acceptable salt concentration and best acceptable cooking time resulted from the previous treatments were used in the treatmentШ. Sub-samples of salted and cooked whole and peeled shrimp (250g each) was selected to determine the optimum drying time and drying temperature. During the drying process, three different time periods were tested (1,2 and 3 hours) at three different temperaturesviz. $50{ }^{\circ} \mathrm{C}, 70{ }^{\circ} \mathrm{C}$ and $90{ }^{\circ} \mathrm{C}$. The first set of samples were oven dried at $50^{\circ} \mathrm{C}, 70{ }^{\circ} \mathrm{C}$ and $90{ }^{\circ} \mathrm{C}$ for one hour and second and third sets of samples were oven dried at two and three hours respectively. Each sample was subjected to sensory evaluation process as described above.

\section{Treatment IV - Evaluation of shelf life under different packaging systems}

Considering the results of the above three experiments, samples of peeled and unpeeled shrimp ( $2 \mathrm{~kg}$ of each) were processed with most 
acceptable salt content, optimum cooking time, optimum drying time and drying temperature. These processed samples were used for evaluation of shelf life under different packaging systems.

Sub-samples of both peeled and unpeeled end product (100g each) were packed using three different packaging systems: polythene bags, Styrofoam boxes and open bulk packages. The packed samples were stored at ambient temperature. Seven samples from each packaging type were analyzed thrice at weekly intervals for the determination of total bacterial counts (TBC), total volatile nitrogen (TVN) and trimethylamine (TMA) contents. TBC of the samples were determined following Speck (1984). TVN and TMN contents in the samples were determined as described by Conway (1968).

\section{Data analysis}

Data are presented as mean \pm standard deviations of a number of replicates. Statistical analysis was carried out using SAS statistical analysis package system (SAS 1985). Analysis of variance, generalized liner model was used to determine least significant differences between treatments at $p<$ 0.05 level.

\section{Results}

Organoleptic scores (saltiness, flavor and texture) given by the trained panel to whole and peeled shrimp treated with different salt concentrations are presented in table 1. Statistical analysis revealed that there are significant differences among the organoleptic scoresThe best preference was given to both whole and unpeeled shrimp treated with $5 \%$ salt content.

Table 2 indicates the organoleptic preference for salted (5\%) whole and peeled shrimp which had been cooked for different time periods. According to the results, 20 minutes cooking time was found to be the best acceptable time for salted whole shrimp. For peeled shrimp, the salted shrimp which had been cooked for 10 minutes was given the maximum preference. Statistical analysis revealed that there are significant differences among organoleptic scores given to the product processed under different cooking times.

Table 3 indicates the organoleptic scores recorded for salted and cooked whole and peeled shrimp dried at different temperatures for different drying times. The drying temperature of $70{ }^{\circ} \mathrm{C}$ was found as the best preferred temperature for both types of shrimp. Organoleptic scores obtained by the product processed under different drying temperatures, $70^{\circ} \mathrm{C}$ was found to be the best acceptable. Considering different drying times, 2 hours drying at $70{ }^{\circ} \mathrm{C}$ was found to be the best. Shrimp stored in Styrofoam boxes (Carton) generally obtained the highest organoleptic scores for both peeled 
and whole (unpeeled) shrimp in comparison to the shrimp stored in polythene or bulk packages (Table 4).

Table 1: Organoleptic quality* of whole and peeled shrimp treated with different salt concentrations $(\%)$.

\begin{tabular}{lrccc}
\hline Shrimp & \multicolumn{4}{c}{ Salt concentration (\%) } \\
\cline { 2 - 5 } & $5.5^{\mathrm{c}} \pm 0.5$ & $7.5^{\mathrm{a}} \pm 0.5$ & $6.5^{\mathrm{b}} \pm 0.5$ & $5^{\mathrm{c}} \pm 0.5$ \\
$\begin{array}{l}\text { Whole } \\
\text { shrimp(unpeeled) }\end{array}$ & & & \\
Peeled shrimp & $6^{\mathrm{b}} \pm 0.4$ & $7^{\mathrm{a}} \pm 0.5$ & $6^{\mathrm{b}} \pm 0.6$ & $4^{\mathrm{c}} \pm 0.7$ \\
\hline
\end{tabular}

*Mean \pm standard deviation of organoleptic scores, $n=3$ samples, judged by 7 trained persons

Means with different superscripts across columns differ significantly. $(\mathrm{p}<0.05)$.

Table 2: Organoleptic scores* of salted $(5 \% \mathrm{w} / \mathrm{w})$ whole and peeled shrimp, cooked at different cooking times.

\begin{tabular}{|c|c|c|c|c|}
\hline \multirow[b]{2}{*}{ Shrimp } & \multicolumn{4}{|c|}{ Cooking times (minutes) } \\
\hline & 10 & 15 & 20 & 25 \\
\hline $\begin{array}{l}\text { Whole } \\
\text { shrimp(unpeeled) }\end{array}$ & $5^{b} \pm 0.57$ & $6^{\mathrm{a}} \pm 0.72$ & $7^{\mathrm{b}} \pm 0.43$ & $5^{\mathrm{c}} \pm 0.31$ \\
\hline Peeled Shrimp & $12^{\mathrm{c}} \pm 0.23$ & $8^{a} \pm 0.54$ & $6.5^{\mathrm{b}} \pm 0.5$ & $4.5^{c} \pm 0.9$ \\
\hline
\end{tabular}

*Mean \pm standard deviation of organoleptic scores, $n=3$ samples, judged by 7 trained persons Means with different superscripts across columns differ significantly. $(\mathrm{p}<0.05)$. 
Table 3: Organoleptic scores* of salted (5\%), cooked and dried whole and peeled shrimp dried under different temperatures and durations

\begin{tabular}{|c|c|c|c|c|c|c|c|c|c|}
\hline \multirow{3}{*}{ shrimp } & \multicolumn{9}{|c|}{ Drying hours and drying temperatures } \\
\hline & \multicolumn{3}{|c|}{ One hour } & \multicolumn{3}{|c|}{ Two hours } & \multicolumn{3}{|c|}{ Three hours } \\
\hline & $50^{\circ} \mathrm{C}$ & $70^{\circ} \mathrm{C}$ & $90^{\circ} \mathrm{C}$ & $50^{\circ} \mathrm{C}$ & $70^{\circ} \mathrm{C}$ & $90^{\circ} \mathrm{C}$ & $50^{\circ} \mathrm{C}$ & $70^{\circ} \mathrm{C}$ & $90^{\circ} \mathrm{C}$ \\
\hline Whole shrimp & $6^{\mathrm{c}} \pm 0.5$ & $7^{b} \pm 0.51$ & $3^{\mathrm{d}} \pm 0.25$ & $8^{\mathrm{ab}} \pm 0.98$ & $9^{\mathrm{a}} \pm 0.56$ & $4^{\mathrm{d}} \pm 0.57$ & $6^{\mathrm{c}} \pm 0.41$ & $7^{b c} \pm 0.67$ & $2^{\mathrm{d}} \pm 0.34$ \\
\hline Peeled shrimp & $5^{c} \pm 0.5$ & $7^{\mathrm{bc}} \pm 0.68$ & $5^{c} \pm 0.57$ & $8^{\mathrm{ab}} \pm 0.76$ & $9^{\mathrm{a}} \pm 0.57$ & $6^{c} \pm 0.67$ & $5^{c} \pm 0.5$ & $6^{\mathrm{c}} \pm 0.5$ & $4^{\mathrm{c}} \pm 0.57$ \\
\hline
\end{tabular}

*Mean \pm standard deviation of organoleptic scores, $\mathrm{n}=3$ samples, judged by 7 trained persons

Means with different superscripts across columns differ significantly. $(\mathrm{p}<0.05)$ - 
Table 4: V ariation in organoleptic scores* of salted (5\%), cooked dried shrimp stored under different packaging systems for six weeks.

\begin{tabular}{|c|c|c|c|c|c|c|c|c|c|c|c|c|}
\hline \multirow[b]{2}{*}{$\begin{array}{l}\text { Mode of } \\
\text { packaging }\end{array}$} & \multicolumn{6}{|c|}{ Whole dried shrimp } & \multicolumn{6}{|c|}{ Peeled dried shrimp } \\
\hline & $\begin{array}{l}1 \\
\text { week }\end{array}$ & $\begin{array}{l}2 \\
\text { weeks }\end{array}$ & $\begin{array}{l}3 \\
\text { weeks }\end{array}$ & $\begin{array}{l}4 \\
\text { weeks }\end{array}$ & $\begin{array}{l}5 \\
\text { weeks }\end{array}$ & $\begin{array}{l}6 \\
\text { weeks }\end{array}$ & $\begin{array}{l}1 \\
\text { weeks }\end{array}$ & $\begin{array}{l}2 \\
\text { weeks }\end{array}$ & $\begin{array}{l}3 \\
\text { weeks }\end{array}$ & $\begin{array}{l}4 \\
\text { weeks }\end{array}$ & $\begin{array}{l}5 \\
\text { weeks }\end{array}$ & $\begin{array}{l}6 \\
\text { weeks }\end{array}$ \\
\hline $\begin{array}{l}\text { Bulk } \\
\text { Package }\end{array}$ & $\begin{array}{l}4.5^{b} \pm \\
0.5^{b}\end{array}$ & $\begin{array}{l}4^{b} \pm \\
0.51\end{array}$ & $\begin{array}{l}3.5^{\mathrm{c}} \pm \\
0.32\end{array}$ & $\begin{array}{l}3^{c} \pm \\
0.47\end{array}$ & $\begin{array}{l}3^{c_{1}} \\
0.73\end{array}$ & $\begin{array}{l}2^{c} \pm \\
0.54\end{array}$ & $\begin{array}{l}8^{\mathrm{a}} \pm \\
0.25\end{array}$ & $\begin{array}{l}7.5^{\mathrm{a}} \pm \\
0.5^{2}\end{array}$ & $\begin{array}{l}7.5^{\mathrm{a}} \pm \\
0.06\end{array}$ & $\begin{array}{l}7.5^{\mathrm{a}} \pm \\
0.54\end{array}$ & $\begin{array}{l}7^{\mathrm{b}} \pm \\
0.73\end{array}$ & $\begin{array}{l}6.5^{\mathrm{b}} \pm \\
0.97\end{array}$ \\
\hline Polythene & $\begin{array}{l}5^{\mathrm{a}} \pm \\
0.5\end{array}$ & $\begin{array}{l}4.5^{\mathrm{a}} \pm \\
0.57\end{array}$ & $\begin{array}{l}4^{b} \pm \\
0.57\end{array}$ & $\begin{array}{l}4^{b} \pm \\
0.55\end{array}$ & $\begin{array}{l}3.5^{\mathrm{b}} \pm \\
0.76\end{array}$ & $\begin{array}{l}3.5^{\mathrm{b}} \pm \\
0.8\end{array}$ & $\begin{array}{l}8^{\mathrm{a}} \pm \\
0.56\end{array}$ & $\begin{array}{l}7.5^{\mathrm{a}} \pm \\
0.97\end{array}$ & $\begin{array}{l}7.5^{\mathrm{a}} \pm \\
0.75\end{array}$ & $\begin{array}{l}7^{b_{ \pm}} \\
0.75\end{array}$ & $\begin{array}{l}6.5^{\mathrm{a}} \pm \\
0.96\end{array}$ & $\begin{array}{l}7^{\mathrm{a}} \pm \\
0.56\end{array}$ \\
\hline Carton & $\begin{array}{l}5^{\mathrm{a}} \pm \\
0.5\end{array}$ & $\begin{array}{l}4.5^{\mathrm{a}} \pm \\
0.76\end{array}$ & $\begin{array}{l}5^{\mathrm{a}} \pm \\
0.5\end{array}$ & $\begin{array}{l}4.7^{\mathrm{a}} \pm 5 \\
0.75\end{array}$ & $\begin{array}{l}4.5^{\mathrm{a}} \pm \\
0.56\end{array}$ & $\begin{array}{l}3.5^{b} \pm \\
0.53\end{array}$ & $\begin{array}{l}8^{\mathrm{a}} \pm \\
0.36\end{array}$ & $\begin{array}{l}7.5^{\mathrm{a}} \pm \\
0.76\end{array}$ & $\begin{array}{l}7.5^{\mathrm{a}} \pm \\
0.64\end{array}$ & $\begin{array}{l}7^{b} \pm \\
0.64\end{array}$ & $\begin{array}{l}6.5^{\mathrm{a}} \pm \\
0.78\end{array}$ & $\begin{array}{l}6^{c} \pm \\
0.45\end{array}$ \\
\hline
\end{tabular}

*Mean \pm standard deviation of organoleptic scores

Means with different superscripts across columns differ significantly. $(\mathrm{p}<0.05)$ - 
Table 5: Total volatile nitrogen (mg/100g), Trimethylamine ( $\mathrm{mg} / 100 \mathrm{~g})$ and Total bacterial count (cfu/g) of salted (5\%), cooked and dried unpeeled shrimps in different packages during six weeks of storage

\begin{tabular}{|c|c|c|c|c|c|c|c|c|c|}
\hline \multirow[b]{2}{*}{$\begin{array}{l}\text { Time } \\
\text { weeks }\end{array}$} & \multicolumn{3}{|c|}{ Total volatile nitrogen $(\mathrm{mg} / 100 \mathrm{~g})$} & \multicolumn{3}{|c|}{ Trimethylamine $(\mathrm{mg} / 100 \mathrm{~g})$} & \multicolumn{3}{|c|}{ Total bacterial count $(\mathrm{cfu} / \mathrm{g})$} \\
\hline & Carton & Normal & Bulk & Carton & Normal & Bulk & Carton & Normal & Bulk \\
\hline 1 & $14.2^{\mathrm{a}} \pm 0.32$ & $15.6^{\mathrm{a}} \pm 0.38$ & $17.8^{b} \pm 0.99$ & $3.73^{\mathrm{a}} \pm 0.88$ & $7.46^{b} \pm 1.3$ & $11.2^{\mathrm{c}} \pm 0.95$ & $\begin{array}{l}1.3 \times 10^{5 \mathrm{a}} \pm \\
0.33\end{array}$ & $\begin{array}{l}4.16 \times 1^{4 b} \\
\pm 0.75\end{array}$ & $\begin{array}{l}8.33 \times 1^{4 c} \\
\pm 0.84\end{array}$ \\
\hline 2 & $11.3^{\mathrm{a}} \pm 0.55$ & $15.2^{\mathrm{b}} \pm 0.85$ & $14.5^{\mathrm{b}} \pm 1.3$ & $6.2^{\mathrm{a}} \pm 0.91$ & $3.53^{\mathrm{b}} \pm 0.77$ & $14.6^{\mathrm{c}} \pm 0.66$ & $\begin{array}{l}1.4 \times 10^{5 \mathrm{a}} \pm \\
50.64\end{array}$ & $\begin{array}{l}1.6 \times 10^{5 \mathrm{a}} \pm 0 \text {. } \\
64\end{array}$ & $\begin{array}{l}1.7 \times 10^{6 \mathrm{c}} \pm 0 . \\
68\end{array}$ \\
\hline 3 & $19.1^{\mathrm{a}} \pm 0.87$ & $22.5^{\mathrm{b}} \pm 0.77$ & $22.0^{\mathrm{b}} \pm 0.88$ & $6.3^{\mathrm{a}} \pm 0.75$ & $11.2^{\mathrm{b}} \pm 0.68$ & $\begin{array}{l}10.1^{\mathrm{b}} \pm \\
0.533\end{array}$ & $\begin{array}{l}1.5 \times 10^{5 \mathrm{a}} \\
\pm 0.98\end{array}$ & $\begin{array}{l}1.5 \times 10^{5 \mathrm{a}} \\
\pm 0.98\end{array}$ & $\begin{array}{l}3.9 \times 10^{4 \mathrm{~b}} \\
\pm 0.88\end{array}$ \\
\hline 4 & $24.0^{\mathrm{a}} \pm 0.22$ & $30.1^{\mathrm{b}} \pm 0.63$ & $32^{\mathrm{b}} \pm 0.75$ & $12.3^{\mathrm{a}} \pm 0.45$ & $12.1^{\mathrm{a}} \pm 0.45$ & $15.2^{\mathrm{b}} \pm 0.94$ & $\begin{array}{l}3.0 \times 10^{5 \mathrm{a}} \pm \\
0.55\end{array}$ & $\begin{array}{l}3.0 \times 10^{5 \mathrm{a}} \\
\pm 0.55\end{array}$ & $\begin{array}{l}7.0 \times 10^{5 b} \\
\pm 0.22\end{array}$ \\
\hline 5 & $27.5^{\mathrm{a}} \pm 0.67$ & $29.0^{\mathrm{b}} \pm 0.75$ & $33^{\mathrm{b}} \pm 0.45$ & $11.2^{\mathrm{a}} \pm 0.36$ & $15.1^{b} \pm 0.55$ & $21.0^{\mathrm{c}} \pm 1.2$ & $\begin{array}{l}4.3 \times 10^{5 a} \\
\pm 0.66\end{array}$ & $\begin{array}{l}4.3 \times 10^{5 \mathrm{a}} \pm \\
0.66\end{array}$ & $\begin{array}{l}1.0 \times 10^{6 \mathrm{~b}} \\
\pm 0.77\end{array}$ \\
\hline 6 & $25.0^{\mathrm{a}} \pm 0.44$ & $34.5^{\mathrm{b}} \pm 0.97$ & $39.5^{\mathrm{c}} \pm 0.32$ & $16.8^{\mathrm{a}} \pm 0.92$ & $21^{\mathrm{b}} \pm 0 . .82$ & $26.3^{\mathrm{c}} \pm 0.93$ & $\begin{array}{l}1.08 \times 10^{6 \mathrm{a}} \pm \\
0.44\end{array}$ & $\begin{array}{l}1.08 \times 10^{6 \mathrm{a}} \\
\pm 0.44\end{array}$ & $\begin{array}{l}1.66 \times 10^{6 \mathrm{~b}} \\
0.25\end{array}$ \\
\hline
\end{tabular}

Data are presented as Mean \pm standard deviation, For a specific parameter, the data in a row indicated with different superscripts are significantly different from each other. $(\mathrm{p}<0.05)$ 
Table 6: Mean value of Total volatile nitrogen $(\mathrm{mg} / 100 \mathrm{~g})$, Trimethylamine $(\mathrm{mg} / 100 \mathrm{~g})$ and Total bacterial count (cfu/g) of salted $(5 \%)$, cooked and dried peeled shrimp at different packages during six weeks

\begin{tabular}{|c|c|c|c|c|c|c|c|c|c|}
\hline \multirow{2}{*}{$\begin{array}{l}\text { Time } \\
\text { (weeks) }\end{array}$} & \multicolumn{3}{|c|}{ Total volatile nitrogen $(\mathrm{mg} / 100 \mathrm{~g})$} & \multicolumn{3}{|c|}{ Trimethylamine $(\mathrm{mg} / 100 \mathrm{~g})$} & \multicolumn{3}{|c|}{ Total bacterial count (cfu/g) } \\
\hline & Carton & Normal & Bulk & Carton & Normal & Bulk & Carton & Normal & Bulk \\
\hline 1 & $\begin{array}{l}3.36^{\mathrm{a}} \pm \\
0.43\end{array}$ & $11.8^{\mathrm{b}} \pm 0.8$ & $10^{b} \pm 0.57$ & $4^{\mathrm{a}} \pm 0.4$ & $7.46^{\mathrm{b}} \pm 1.3$ & $10.6^{\mathrm{c}} \pm 0.8$ & $\begin{array}{l}1.0 \times 10^{3 \mathrm{a}} \\
\pm 0.53\end{array}$ & $\begin{array}{l}2 . \times 10^{4 b} \\
\pm 0.86\end{array}$ & $\begin{array}{l}8.33 \times 1^{4 c} \\
\pm 0.83\end{array}$ \\
\hline 2 & $6^{\mathrm{a}} \pm 0.22$ & $5.4^{\mathrm{a}} \pm 0.3$ & $13^{\mathrm{b}} \pm 0.4$ & $7^{\mathrm{a}} \pm 0.9$ & $3.5^{\mathrm{b}} \pm 0.7$ & $15^{\mathrm{c}} \pm 0.7$ & $\begin{array}{l}2.0 \times 10^{5 \mathrm{a}} \\
\pm 0.53\end{array}$ & $\begin{array}{l}1.6 \times 10^{5 \mathrm{~b}} \pm \\
0.64\end{array}$ & $\begin{array}{l}2.0 \times 10^{4 c} \\
\pm 0.31\end{array}$ \\
\hline 3 & $3^{\mathrm{a}} \pm 0.68$ & $10.1^{\mathrm{b}} \pm 0.9$ & $15^{\mathrm{b}} \pm 0.75$ & $6.3^{\mathrm{a}} \pm 0.7$ & $8^{b} \pm 0.5$ & $9^{b} \pm 0.8$ & $\begin{array}{l}2.0 \times 10^{4 a} \\
\pm 0.94\end{array}$ & $\begin{array}{l}1.5 \times 10^{5 b} \\
\pm 0.98\end{array}$ & $\begin{array}{l}6.0 \times 10^{4 a} \\
\pm 0.88\end{array}$ \\
\hline 4 & $4.9^{\mathrm{a}} \pm 0.9$ & $10.1^{\mathrm{b}} \pm 0.9$ & $16.3^{c} \pm 0.2$ & $12.3^{\mathrm{a}} \pm 0.5$ & $10.5^{\mathrm{b}} \pm 0.9$ & $15.1^{\mathrm{c}} \pm 0.6$ & $\begin{array}{l}0.4 \times 10^{4 a} \\
\pm 0.55\end{array}$ & $\begin{array}{l}3.0 \times 10^{5 b} \\
\pm 0.55\end{array}$ & $\begin{array}{l}1.5 \times 10^{5 \mathrm{c}} \\
\pm 0.74\end{array}$ \\
\hline 5 & $6.72^{\mathrm{a}} \pm 0.5$ & $15^{\mathrm{b}} \pm 0.8$ & $17^{b} \pm 0.92$ & $11.2^{\mathrm{a}} \pm 0.3$ & $10^{\mathrm{b}} \pm 0.1$ & $20^{\mathrm{c}} \pm 1.3$ & $\begin{array}{l}5.0 \times 10^{4 a} \\
\pm 0.99\end{array}$ & $\begin{array}{l}4.3 \times 10^{5 b} \\
\pm 0.66\end{array}$ & $\begin{array}{l}2.0 \times 10^{5 b} \\
\pm 0.77\end{array}$ \\
\hline 6 & $27^{\mathrm{a}} \pm 0.34$ & $16.8^{\mathrm{b}} \pm 0.9$ & $21^{\mathrm{c}} \pm 0.98$ & $16.8^{\mathrm{a}} \pm 0.9$ & $15^{\mathrm{b}} \pm 0.7$ & $25.2^{c} \pm 0.7$ & $\begin{array}{l}7.0 \times 10^{4 a} \\
\pm 0.24\end{array}$ & $\begin{array}{l}1.6 \times 10^{6 \mathrm{~b}} \\
\pm 0.24\end{array}$ & $\begin{array}{l}3.0 \times 10^{5 \mathrm{c}} \\
\pm 0.11\end{array}$ \\
\hline
\end{tabular}

Data are presented as Mean \pm standard deviation. For a specific parameter the data in a row indicated with different superscript are significantly different from each other. $(\mathrm{p}<0.05)$ 
Tables 5 and 6 show the changes in TVN, TMN and TBC for whole and peeled dried shrimp stored at ambient temperature under different packaging systems. The TVN contents of the both bulk packed peeled and unpeeled shrimps were relatively high. This value ranged from 17.8 to $39.5 \mathrm{mg} / 100 \mathrm{~g}$ unpeeled shrimp in bulk packages over the six weeks storage period. The TVN values of shrimp stored in Styrofoam packs were significantly lower than those stored in the other packages.

The peeled shrimp in open bulk package, had the highest TMA range (10.6 to $25.2 \mathrm{mg} / 100 \mathrm{~g}$ ) during six weeks. The lowest TMA ranges (4 to 16.8 and 7.46 to $15 \mathrm{mg} / 100 \mathrm{~g}$ ) were recorded for the samples packed in Styrofoam and polythene packed samples respectively. For the whole dried shrimp, the lowest TMA ranges (3.73 to $16.8 \mathrm{mg} / 100 \mathrm{~g}$ ) were recorded for packs in Styrofoam boxes. The highest TMA range (11.2 to $26.3 \mathrm{mg} / 100 \mathrm{~g})$ was recorded for the samples packed in bulk packages.

TBC values recorded for the unpeeled shrimp stored in Styrofoam boxes and polythene were significantly lower than those values recorded for the samples stored in bulk packaging methods. TBC values of the peeled shrimp stored in Styrofoam boxes were significantly lower when compared to the other packaging methods (Table 5 and 6). However the TBC increased from $1.3 \times 10^{5}$ to $1.08 \times 10^{6} \mathrm{cfu} / \mathrm{g}$ in whole shrimp stored in Styrofoam boxes over the six weeks storage period.

\section{Discussion}

In the present study, salting at 5\% level followed by pressure cooking for 20 minutes and drying for 2 hours at $70^{\circ} \mathrm{C}$ were found to be the preferred method of processing that resulted in the most acceptable end product for whole dried shrimp. For peeled dried shrimp, salting at 5\% level, and pressure cooking for 10 minutes followed by drying for 2 hours at $70^{\circ} \mathrm{C}$ were the most acceptable conditions for processing. Zaitsev et al. (1969) stated that the process of peeled dried shrimp consumes less time compared to the whole dried shrimp as indicated in the present study.

The most palatable salt content of the product is $5 \%$ for both peeled and whole (unpeeled) shrimp. This is due to enhanced water protein relationships of the product. However, addition of salt disturbed the flavor properties of the raw shrimp. The most acceptable time for cooking for $5 \%$ salted, whole shrimp is 20 minutes. The 20 minute heating period appeared to accelerate the nutritional reactions and improve the colour and flavours in the product. The biological reactions have an optimum temperature at which the reaction rate reaches a maximum as pointed out by Price and Schweiger (1971). It also accelerates the amino-sugar reactions and improves the colour and flavour properties in the product. 
In the present study, shrimp packed in Styrofoam box showed significantly lower bacterial growth. Styrofoam packages have very much effective barrier properties, resist bacterial contaminations and reduce the bacterial multiplication inside the package. TMA and TVN values are quality indicators of the processed product and the upper recommended values are 12 and $30 \mathrm{mg} / 100 \mathrm{~g}$ respectively. For whole shrimps stored in Styrofoam boxes, polythene and packed in bulk had the respective optimum storage times between three and five weeks. Same trend was observed for peeled shrimp as well. TVN concentration in the shrimp did not exceed the recommended levels in all packages. The maximum shelf life of five weeks is recommended for Styrofoam for both types of shrimp packages

\section{References}

Conway, E.J. 1968.

Microdifiusion Analysis and V olumetric Error, th ed., Lock Wood and sons, Crossly, London.

Price, J.F. \& Schweigert, B.S. 1971.

The Science of Meat and Meat Products $2^{\text {nd }}$ edition. San Francisco:

Freeman

SAS, 1985.

SAS user's Guide: Statistics, Computer added soft ware. Statistical analysis system for personnel computers version 6.012, Insitute Inc,. Cary, NC, USA,

Soudan, F. 1978.

Methodology of Organoleptic Examination FAO/ DANIDA Workshop on Fish Technology \& Inspections, 16 October-25, November, FAO, FII:IFTI/78/13

Speck, M.L. 1984.

Compendium of Methods for the Microbiological Examination of Foods., Alpha technical committee on microbiological methods for foods. 318p.

Jayasinghe, J.M.P.K. 1995.

Shrimp culture in Sri Lanka, Annual Scientific Session, National Aquatic Resource and Development Agency, Crow Island, Colombo. 33-45.

Zaitsev, V, I. Kizevetter, I. Lagnov \& T. Makarova 1969.

Marinating, Salting and Processing. Fish curing and processing. MIR Publishers, Moscow, 249p. 
